PAWEE TOPOL

ORCID 0000-0002-9810-7214

Uniwersytet im. Adama Mickiewicza

$w$ Poznaniu

\title{
METODY I NARZĘDZIA KSZTAŁCENIA ZDALNEGO W POLSKICH UCZELNIACH W CZASIE PANDEMII COVID-19 - CZĘŚĆ 1, DYSKUSJA 2020
}

\begin{abstract}
AвSTRAct. Topol Paweł, Metody i narzędzia kształcenia zdalnego w polskich uczelniach w czasie pandemii COVID-19 - Część 1, Dyskusja 2020 [Distant Learning Methods and Tools in Polish Higher Education During the COVID-19 pandemic - Part 1, 2020 Debate]. Studia Edukacyjne nr 58, 2020, Poznań 2020, pp. 69-83. Adam Mickiewicz University Press. ISSN 1233-6688. DOI: 10.14746/se.2020.58.4

The coronavirus has left its mark on practically every branch of the economy in Poland and has affected all spheres of human life: public, professional and private. Education is no exception. Distance learning, or e-learning, has a rich history in education. So far, however, e-learning has acted as a kind of "adjunct" to traditional classroom learning and as an alternative to face-to-face classes. The coronavirus disease forced a completely new situation in Polish education. All, or almost all, traditional forms of teaching and learning had to shift towards remote, virtual forms.

In the first half of this year (2020), an extensive discussion at the SEA forum (the Academic E-learning Association) took place. Scientists, educators and technical experts from various academic centers spoke about the methods and tools launched in their institutions. This article offers a synthesis of that discussion, i.e. how certain Polish universities eventually did or did not succeed in the above matter. The article is based on selected fragments and quotes of the debate. Some of them were briefly commented on by the author.
\end{abstract}

Key words: COVID-19, higher education, e-learning, virtual education, online applications

\section{Wstęp}

Artykuł składa się z kilku części. Pierwsza wprowadza w wybrane zagadnienia kształcenia zdalnego w Polsce, z krótkim przywołaniem jego początków. Podano tutaj trzy przykłady pionierskich inicjatyw akademickich, które zrodziły się na przełomie lat 2000 i 2001. W tej samej części dokonano 
pewnych uściśleń definicyinnych gdyż e-learning rozumiany jako wyłącznie kształcenie na odległość z wykorzystaniem Sieci/Internetu nie ma umocowania etymologicznego.

Część druga dotyczy krótko i wybiórczo nowych wyzwań, przed jakimi stanął e-learning w tym roku kalendarzowym. Dotychczas był alternatywą dla systemu klasowo-lekcyjnego i, prawdę mówiąc, dodatkiem do niego, nie zawsze docenianym czy traktowanym przychylnie przez decydentów edukacyjnych, w przeciwieństwie oczywiście do entuzjastów edukacji e-. Przywołano tu stojące w opozycji do siebie kierunki konektywizmu i dysocjacji. Pandemiczna rzeczywistość 2020 roku - o czym mowa dalej - zmieniła jednak spojrzenie na e-learning znacząco, gdyż wymusiła tę formę kształcenia w Polsce nagle i globalnie.

Ostatnia część ma charakter bardzo praktyczny, wręcz narzędziowy, traktuje bowiem właśnie o metodach i narzędziach e-learningowych stosowanych w polskich uczelniach $w$ obecnym okresie pandemii COVID-19. Jest to skrót, swoisty raport z dyskusji, która odbyła się w gronie akademickim na forum Stowarzyszenia E-learningu Akademickiego. Edukatorzy dzielili się rozwiązaniami stosowanymi w ich własnych ośrodkach. Dyskusja ta miała służyć wszystkim członkom forum w Polsce i dać przybliżony obraz oparty na szczegółowych przykładach, jak wybrane instytucje różnie wdrażają i stosują tytułowe metody i narzędzia, i z jakim skutkiem. Stąd niekiedy wręcz poradnikowy jej charakter.

\section{O edukacji zdalnej krótko}

\section{Kształcenie na odległość w Polsce}

W obliczu powszechnego zagrożenia koronawirusem, polska edukacja stanęła przed całkowicie nowym wyzwaniem. Wraz z rosnącym zagrożeniem zarażenia się, zamykane były do odwołania instytucje dostępu publicznego. Dydaktyka tradycyjna w systemie klasowo-lekcyjnym przekształciła się w całości lub w znaczącej mierze - w tak zwane kształcenie zdalne, zwane czasami kształceniem na odległość. Intencjonalnie użyto zwrotu "tak zwane”, bowiem kwestia odległości jest tutaj umowna. Chodzi o przeniesienie dydaktyki na grunt wirtualny, a fizyczna odległość między osobami uczestniczącymi w procesie dydaktycznym nie ma większego znaczenia. Nauczanie i uczenie się odbywa się za pośrednictwem mediów oraz narzędzi elektronicznych dostępnych w Sieci.

Kształcenie zdalne z wykorzystaniem nośników elektronicznych ma długą historię w polskiej edukacji. Wydaje się, że rok 2000 i następne były okresem upowszechniania narzędzi e-learningowych w polskich uczel- 
niach. Z racji ograniczonej objętości niniejszego tekstu przywołajmy trzy wybrane, choć charakterystyczne przykłady. Po pierwsze, w 2001 roku zostało uruchomione Uniwersyteckie Centrum Zdalnego Nauczania i Kursów Otwartych Uniwersytetu Marii Curie-Skłodowskiej w Lublinie. Celem „UCZNiKO” było i jest przygotowanie, prowadzenie i realizacja projektów związanych z szeroko pojętym wykorzystaniem Internetu w edukacji $\mathrm{w}$ szkole wyższej ${ }^{1}$. Drugi przykład pochodzi z roku akademickiego 2000/2001, a było to pierwsze w Polsce ogólnokrajowe "Studium Projektowania Programów Nauczania", prowadzone przez Internet, przeznaczone dla doradców metodycznych i nauczycieli zainteresowanych pogłębieniem wiedzy oraz rozwinięciem umiejętności budowania programów szkolnych. Studium zostało zaprojektowane oraz przeprowadzone przez pracowników naukowych Wydziału Studiów Edukacyjnych UAM w Poznaniu (S. Dylak, P. Topol i W. Skrzydlewski) i w pierwszej edycji objęło kilkadziesiąt osób z całej Polski ${ }^{2}$. Trzeci i ostatni tutaj przykład stanowi znany wszystkim Polski Uniwersytet Wirtualny (PUW)3 , który w 2002 roku uruchomił w Łodzi studia na dwóch kierunkach: zarządzanie i marketing oraz informatyka. Obecnie PUW prowadzi studia licencjackie i inżynierskie I stopnia (kilkanaście kierunków), studia magisterskie II stopnia oraz jednolite studia magisterskie, studia podyplomowe (ponad 30 kierunków) ${ }^{4}$, a także - jak czytamy w notce informacyjnej - „szeroki pakiet kursów dokształcających”.

\section{Uściślenie definicyjne}

W kontekście kształcenia na odległość lub zdalnego często używa się określenia e-learning. Nie jest to do końca precyzyjne. Co zatem etymologicznie oznacza owo „e-"? Oznacza ni mniej, ni więcej, co electronic. Zatem, e-learning jest uczeniem się wspomaganym narzędziami i nośnikami elektronicznymi, a dydaktyka zdalna jest tyko jedną z możliwych form. W e-learningu mieszczą się zatem wszelakie materiały do pracy również stacjonarnej, byle stosowane z wykorzystaniem urządzeń elektronicznych. Będą to między innymi wydawnictwa na płytach CD, DVD lub innych nośnikach instalowane na komputerze lokalnym: encyklopedie multimedialne, kursy, zestawy zadań lub ćwiczeń, materiały poglądowe, wykłady i tym podobne.

Cóż zatem stało się z pojęciem e-learningu na przestrzeni lat? Otóż, w języku polskim (choć nie tylko) określenie to stało się pewnym hasłem-wytrychem. E-learning sprowadzono semiotycznie właśnie do form zdalnych, na odległość. Zostańmy zatem przy tej nowo przyjętej definicji. Dla uprosz-

\footnotetext{
${ }^{1}$ http://www.uczniko.umcs.lublin.pl/art.php?catID=1\&artID =1 [dostęp: 10.05.2016].

2 http://topol.home.amu.edu.pl/projekty/ppn.html [dostęp: 15.07.2020].

${ }^{3}$ https://www.puw.pl/pl [dostęp: 10.11.2019].

${ }^{4}$ https://www.puw.pl/pl/studia-online [dostęp: 10.11. 2019].
} 
czenia, w niniejszym artykule będą używane zamiennie określenia e-learning, kształcenie zdalne i kształcenie na odległość.

\section{Edukacja wobec nowych wyzwań w dobie pandemii}

\section{Od konektywizmu do dysocjacji}

E-learning stanowił przez wszystkie lata swojej historii jedną $\mathrm{z}$ form prowadzenia dydaktyki na uczelniach wyższych, nie tylko w Polsce. Był zawsze traktowany jako alternatywa dla form tradycyjnych, czyli systemu klasowo-lekcyjnego, stanowiąc de facto dopełnienie, uzupełnienie, czy dodatek do wszechobecnego nauczania w systemie bezpośrednim twarzą w twarz. Pomijamy oczywiście instytucje edukacyjne działające w całości on-line. Sasha Reese (Indiana University of Pennsylvania, USA) ciekawie opisała jeszcze w 2014 roku dwoistość wirtualnych środowisk edukacji (VLE) we współczesnym kształceniu akademickim: od konektywizmu do dysocjacji ${ }^{5}$. Obydwa kierunki stoją w opozycji do siebie, gdyż: (a) zwolennicy VLE przekonują, że uczeń/student XXI wieku jest skutecznie wyposażony i wyposażany w narzędzia wirtualne - bazujące głównie na Web 2.0, a (b) sceptycy twierdzą, że wirtualne narzędzia komunikacji asynchronicznej nie spełniają pokładanych w nich nadziei na znaczące usprawnienie procesu uczenia się u studentów, między innymi z powodu swoistego odosobnienia ${ }^{6}$.

Oprócz organizacji kształcenia zdalnego w układzie pionowym (zstępującym) nauczyciel $\rightarrow$ uczeń, ważną rolę odgrywa taka organizacja procesu kształcenia, aby aktywować w możliwie skuteczny sposób komunikację w układzie poziomym: uczeń $\rightarrow$ uczeń. W obecnych czasach zagrożenia, kiedy podróże oraz kontakty między uczniami/studentami są z natury ograniczone, współpraca zdalna może przynieść wymierne efekty. Pisze o tym między innymi Mary Masterson (University of Limerick, Ireland), która zorganizowała długofalową współpracę on-line w nauce języka obcego pomiędzy uczniami różnych krajów i kultur. Okazało się, że dobrze zaprojektowany kurs oraz sprawne jego przeprowadzenie dały wśród uczniów podobnie pozytywne wyniki, jak te sprzed pandemii ${ }^{7}$.

\section{E-learning w rzeczywistości 2020}

Zupełnie nową sytuacją dla szkolnictwa wyższego i nie tylko (w odniesieniu do przywołanego powyżej roku 2014) był/jest rok 2020, czyli okres pande-

${ }^{5} \mathrm{~S}$. Reese, Online learning environments in higher education: Connectivism vs. dissociation, Education and Information Technologies, 2015, 20, s. 579-588.

${ }^{6}$ Por.: A. Bejerano, The genesis and evolution of online degree programs: who are they for and what have we lost along the way?, Communication Education, 2008, 57(3), s. 408-414.

7 M. Masterson, An Exploration of the Potential Role of Digital Technologies for Promoting Learning in Foreign Language Classrooms: Lessons for a Pandemic, jET, 2020, 15, 14, s. 83-96. 
mii koronawirusa. Edukacja stanęła wobec całkiem nowych i bezprecedensowych wyzwań. Pojawiła się konieczność całkowitego przejścia z tradycyjnych klasowo-lekcyjnych form kształcenia na te całkowicie w trybie wirtualnym. $\mathrm{Z}$ racji specyfiki tego tekstu, ograniczymy się do szkolnictwa wyższego.

Powyższe wyzwania pandemiczne dotknęły wszystkich uczestników procesu kształcenia: władze uczelniane i wydziałowe, wykładowców i edukatorów, administrację oraz oczywiście studentów. Działania władz i edukatorów musiały skoncentrować się na takim przygotowaniu procesu edukacyjnego, aby stworzyć dla studentów optymalne warunki zdobywania wiedzy i kształtowania umiejętności. Także działania administracji zostały skierowane na podejmowanie czynności i wytworzenie nowych lub zmodyfikowanych form pracy, aby jednocześnie możliwie zredukować bezpośredni kontakt międzyludzki. Skoncentrujmy się na organizacji procesu kształcenia i nauki, pomijając większość zagadnień administracyjnych.

\section{Metody i narzędzia kształcenia zdalnego w polskich uczelniach, 2020}

Niniejsza część będzie poświęcona dyskusji na temat metod i narzędzi wykorzystywanych w wybranych polskich uczelniach wyższych w czasie pandemii koronawirusa. Dyskusja ta miała miejsce na zamkniętym forum ogólnopolskiego Stowarzyszenia E-learningu Akademickiego ${ }^{8}$ (SEA). Stowarzyszenie prowadzi bardzo aktywną działalność od 2006 roku. Jest to konstrukt formalny, który działa na rzecz promocji i rozwoju e-edukacji w szkolnictwie wyższym. Oto krótki fragment noty prasowej dla pisma E-Mentor z początku działalności Stowarzyszenia:

...przechodzimy do fazy dojrzałego rozwoju e-learningu akademickiego w Polsce. Fazy, w której nie tylko będziemy dzielić się swoimi doświadczeniami na licznych seminariach czy konferencjach, ale także wspólnie działając - tworzyć wzorce dobrych praktyk e-edukacyjnych oraz je propagować - przyczyniając się w ten sposób do rozwoju e-learningu w Polsce? .

SEA oferuje także bezpłatne szkolenia, które kończą się certyfikacją specjalistów „e-" w dwóch kategoriach: e-nauczyciela i e-metodyka ${ }^{10}$. Pierwszy wymaga między innymi potwierdzenia doświadczenia w prowadzeniu

${ }^{8}$ Stowarzyszenie E-learningu Akademickiego, strona główna: https://sea.edu.pl/ [dostęp: 15.07 .2020$]$.

${ }^{9}$ Stowarzyszenie E-learningu Akademickiego - Informacja prasowa, E-mentor, 2006, $4(16)$, s. 4.

${ }^{10}$ Stowarzyszenie E-learningu Akademickiego, certyfikacje e-nauczyciela i e-metodyka: https://sea.edu.pl/certyfikacja.php [dostęp: 15.07.2020]. 
kształcenia on-line (adresy kursów, zrzuty ekranowe, ewentualna ewaluacja itp.), które musi być poparte zgromadzoną dokumentacją formalną. Drugi natomiast kończy się dwuczęściowym egzaminem.

SEA działa nie tylko centralnie, ale także - lub może przede wszystkim - poprzez lokalne zespoły funkcjonujące w miastach-ośrodkach akademickich. Zespoły odbywają regularne spotkania, na których podnoszone są różne kwestie e-edukacji o zasięgu lokalnym lub w wymiarze ogólnopolskim. Niektóre zespoły mają na koncie całkiem spory dorobek publikacyjny w punktowanych periodykach polsko- i obcojęzycznych.

Właśnie głosy płynące z owych lokalnych ośrodków złożyły się na wspólną debatę na temat jakości kształcenia zdalnego na poziomie akademickim w dobie pandemii COVID-19. Odbyła się ona w pierwszej połowie tego roku (2020). W debacie tej uczestniczyli wykładowcy, edukatorzy i specjaliści z zakresu stosowania oraz zarządzania technologiami informacyjnymi i infrastrukturą informatyczną. Dzielili się:

- stosowanymi rozwiązaniami organizacyjnymi;

- stosowanymi metodami i wykorzystywanymi narzędziami;

- uwagami szczegółowymi względem cech, a nawet funkcji określonych aplikacji komputerowych.

Wątek dyskusji na forum SEA brzmiał: „Rozwój e-learningu w obecnych warunkach - jak sobie radzimy?"11. Dostęp do tego wątku forum mają członkowie Stowarzyszenia. Stąd, zrodził się pomysł upowszechnienia tej dyskusji w publikacji ogólnodostępnej.

\section{Raport z dyskusji akademickiej 2020}

Poniżej zaprezentowano niektóre wypowiedzi uczestników debaty, których fragmenty zostaną zacytowane ${ }^{12}$. Będzie to stanowiło pewien skrót, jako że niektóre osoby wypowiadały się kilkakrotnie. Poza tym, zakres objętościowy niniejszego tekstu nie pozwala na cytowanie dyskusji w całości.

Wypowiedzi zostały podzielone według afiliacji i ułożone w porządku alfabetycznym. Niektóre z nich pozwoliłem sobie opatrzyć krótkim komentarzem sygnowanym przez [Komentarz: PT]. Poszczególne teksty przywołuję $\mathrm{w}$ oryginale, nie ingerując $\mathrm{w}$ ich stronę formalną.

\section{Akademia Górniczo-Hutnicza - Centrum e-Learningu AGH (Agnieszka Chrząszcz) \\ Platforma UPEL oparta na Moodle wraz z wtyczką Virtual Class od Click- meeting (tutaj wykorzystywane przez nas wtyczki ${ }^{13}$ ) musiała obsłużyć kil-}

\footnotetext{
${ }^{11}$ https://moodle.sea.edu.pl/mod/forum/discuss.php?d=1276 [dostęp: 31.07.2020].

12 Wszystkie wypowiedzi cytowane są za indywidualną zgodą Autorów [przyp. aut.].

${ }^{13}$ https://upel.agh.edu.pl/kokpit/wtyczki.html [dostęp: 15.05.2020].
} 
kusetprocentowy wzrost liczby jednocześnie zalogowanych użytkowników. W pierwszym tygodniu (od 12.3) powstało 2700 nowych kont i ponad 900 nowych kursów. Do 17.4 w sumie uruchomiono ponad 1800 nowych kursów, zaś na platformie aktywnych jest ponad 58000 kont. W szczycie ruchu to około 500. jednoczesnych użytkowników. Na UPEL-u jednocześnie może być prowadzonych 100 wykładów czy spotkań dla 100 osób każdy (Virtual Class) i są dni, kiedy ten limit jest wyczerpany, średnio dziennie prowadzonych jest około 60 równoległych spotkań. Dodatkowo, Uczelniane Centrum Informatyki wdrożyło system Microsoft Teams. W AGH:

- ad. IDENTYFIKACJA: nie identyfikujemy i nie planujemy tego robić. $\mathrm{W}$ tak krótkim czasie i przy takiej skali wdrożenie jakiegokolwiek systemu oceniliśmy jako niewykonalne. W przypadku egzaminów dyplomowych sprawdzenie dowodu przez Komisję. Uczestnicy logują się do systemu ze stałych adresów, swoimi mejlami itp.;

- ad REJESTRACJA: Virtual Class umożliwia rejestrację egzaminów ustnych. UPEL umożliwia rejestrację działań na platformie (logi). Innych narzędzi na razie nie przewidujemy;

- ad. INTERPRETACJA: jest taka, że uczelnia będzie weryfikowała efekty kształcenia tam gdzie to możliwe, przeprowadzając zaliczenia, egzaminy i egzaminy dyplomowe $\mathrm{z}$ wykorzystaniem wdrożonych do tej pory narzędzi.

[Komentarz: P.T.] Post pochodzi z kwietnia 2020. Brak jest dotąd (lipiec-sierpień) informacji o ewentualnie przeprowadzonych zaliczeniach $i$ egzaminach na koniec roku oraz na temat zastosowanych narzędzi.

Politechnika Łódzka (Jacek Stańdo)

W Politechnice Łódzkiej od wielu lat działa Centrum E-learningu. W ciągu kilku dni nauczyciele akademiccy przeszli z tradycyjnego kształcenia na kształcenie na odległość. Platforma e-learningowa WIKAMP działająca w Politechnice Łódzkiej może obsłużyć jednocześnie wszystkich studentów, czyli około 20 tysięcy. Każdego dnia odbywa się ponad 100 wykładów on-line.

[Dodatkowa wypowiedź J. Stańdo zamieszczona na blogu Bogusława Śliwerskiego (sugestia autora notki) ${ }^{14}$.

Wielu pyta mnie jak to możliwe, że studenci przez 24 godziny na dobę mają w Sieci dostępne zadania nawet $\mathrm{z}$ możliwością rozwiązywania ich na telefonach, a następnie $\mathrm{z}$ tych zadań w czasie sesji będą zdawać egzamin? Tak, to jest możliwe, ponieważ rozwiązania problemu nie da się nauczyć, trzeba je po prostu zrozumieć. Więcej, liczbę testów (egzaminacyjnych) można wygenerować, tyle ile jest...: Uwaga!, we wszechświecie atomów. Dla wszystkich uczniów na świecie, dla ich dzieci, ich wnuków i prawnuków dla wszystkich

${ }^{14}$ https://sliwerski-pedagog.blogspot.com/2020/05/jakie-mozliwosci-daja-webinaria. html [dostęp: 15.05.2020]. 
wystarczy testów i to dla każdego inny. Ale najważniejsze: mierzą one ten sam zestaw efektów uczenia się. To nie jest jedna próbna matura i to w dodatku z ubiegłego roku.

\section{Szkoła Wyższa im. Pawła Włodkowica w Płocku (Robert Żak)}

Korzystamy od wielu lat z platformy WLODEK opartej na systemie MOODLE. Każdy student na I semestrze realizuje kurs e-learningowy i potrafi praktycznie korzystać z platformy. Po przejściu na nauczanie na odległość zainstalowaliśmy własną instancję serwera BigBlueButton i dodaliśmy kształcenia synchroniczne. W marcu przeprowadziliśmy dodatkowe szkolenia dla wykładowców i ruszyliśmy z cyklicznymi zajęciami on-line. Infrastruktura umożliwia nam prowadzenie jednocześnie 5 sesji BigBlueButton dla maksymalnie 80 osób w jednej sesji. (...) Po miesiącu intensywnej pracy wielkość zasobów wzrosła dwukrotnie i musimy dokupić nowe dyski do macierzy. Niestety, początkowy entuzjazm wykładowców pomału opada ze względu na obciążenie pracą. Studenci też nie są zachwyceni, ale bardziej wynika to z ich sytuacji - obowiązków rodzinnych i konieczności dzielenia komputera z pozostałymi domownikami.

Rozbudowaliśmy dwukrotnie serwer i zwiększyliśmy liczbę webinariów do 10 równoległych sesji (ponad 100 godzinnych sesji dziennie) - praktycznie zaspokaja to nasze potrzeby. Zwiększenie liczby webinariów wynikało głównie z zapotrzebowania zgłaszanego przez studentów - jest to dla nich łatwiejsza i mniej wymagająca forma zajęć, niż samodzielna realizacja zadań i projektów. Ważnym aspektem było też prowadzenie lektoratów z języków obcych w małych grupach i na różnych poziomach.

Uniwersytet im. Adama Mickiewicza w Poznaniu - Wydział Matematyki i Informatyki, Zakład Sztucznej Inteligencji (Barbara Kołodziejczak)

UAM prowadzi nauczanie zdalne, korzystając z Microsoft Teams oraz platform Moodle (osobnych dla każdego wydziału). Aplikacja Microsoft Teams wspierana jest, $\mathrm{w}$ zakresie zarządzania zespołami dydaktycznymi, napisaną specjalnie dla UAM, aplikacją Panel Dydaktyczny. Oczywiście, nauczyciele mogą korzystać również z innych narzędzi i środowisk edukacyjnych. Zajęcia zdalne prowadzone są na tych przedmiotach, dla których 2/3 studentów wyraziło chęć i zadeklarowało możliwości techniczne niezbędne do uczestnictwa. Zgody zbierane były centralnie, z wykorzystaniem przygotowanego systemu ankietowego. Dla Uczelni przygotowano wytyczne dotyczące różnych form zajęć zdalnych zastępujących kształcenie tradycyjne.

Wsparciem technicznym i metodycznym służą nauczycielom akademickim i studentom pracownicy Centrum Informatycznego UAM i Ośrodka Wsparcia Kształcenia na Odległość ${ }^{15}$ oraz wydziałowi koordynatorzy ds. e-le-

\footnotetext{
${ }^{15}$ https://www.elearning.amu.edu.pl/owko/ [dostęp: 15.04.2020].
} 
arningu. Przygotowali oni dużo informacji, opracowali wiele instrukcji, także $\mathrm{w}$ formie filmów instruktażowych. Specjaliści odpowiadają również na bieżąco na pytania pracowników. Organizowane są webinaria, w ramach których prezentowane są możliwości poszczególnych narzędzi informatycznych. Ponadto, dla wszystkich uczestników zajęć dydaktycznych na odległość przygotowano pomocne informacje z zakresu prawa autorskiego, uwzględniające wybrane aspekty pracy dydaktycznej w środowisku cyfrowym.

[Komentarz: P.T.] B. Kołodziejczak wypowiedziała się jako pracownik UAM, jednak - jak sądzę - również z perspektywy własnego wydziału. Na zakończenie prezentacji dyskusji pozwole sobie na krótki głos własny z perspektywy Wydziału Studiów Edukacyjnych UAM.

\section{Uniwersytet Jagielloński - Centrum Zdalnego Nauczania (Jacek Urba- niec)}

[Komentarz: P.T.] Wypowiedź została poparta artykułem opublikowanym w periodyku "Forum Akademickie"16. Oto fragment w cytacie:]

W UJ mieliśmy jeden wyjątek, nie tylko na skalę polską. Władze dziekańskie Wydziału Lekarskiego jeszcze w poprzednim roku akademickim zadecydowały o rezygnacji z tradycyjnych wykładów i stopniowym (w okresie 2 lat) przechodzeniu na e-wykłady na platformie zdalnego nauczania. W każdym razie, w roku akademickim 2018/2019 mieliśmy w sumie w Uniwersytecie 5468 zajęć aktywnych na naszej platformie zdalnego nauczania, co stanowiło $12,4 \%$ wszystkich zajęć dydaktycznych w UJ. Wprawdzie jak na polskie warunki był to $\mathrm{w}$ miarę dobry wynik, ale $\mathrm{z}$ drugiej strony w praktyce oznaczał on, że co najmniej 4. na 5. nauczycieli akademickich nie miało $\mathrm{w}$ ogóle styczności z nauczaniem zdalnym. Wybuchła pandemia i nagle z dnia na dzień $80 \%$ nauczycieli akademickich jednym zarządzeniem rektora UJ musiało zupełnie zmienić metody kształcenia. Podobnie było na innych uczelniach. Pokazuje to skalę wyzwania, przed którym niespodziewanie stanęła edukacja uniwersytecka. Czy byliśmy do tego przygotowani? Powiedzmy szczerze - nie. Ani z punktu widzenia formalnoprawnego (wspomniane rozporządzenie MNiSW), ani infrastrukturalnie (infrastruktura informatyczna nie uwzględniała gwałtownego kilkukrotnego wzrostu użytkowników w przeciągu kilku dni), ani metodycznie (dla przykładu $\mathrm{w}$ nieobowiązkowych szkoleniach $\mathrm{z}$ obsługi platform zdalnego nauczania wraz z metodyką nauczania zdalnego uczestniczyło każdego roku najwyżej stu kilkudziesięciu pracowników UJ).

${ }^{16}$ J. Urbaniec, Edukacja „pandemiczna" czyli o kształceniu zdalnym na uczelniach, Forum Akademickie, 2020, 05; https://miesiecznik.forumakademickie.pl/czasopisma/fa-05-2020/edukacja -pandemiczna \%E2\% 80\%A8czyli-o-ksztalceniu-zdalnym-na-uczelniach\%E2\%80\%A9/ [dostęp: 15.06.2020]. 
Uniwersytet Medyczny w Poznaniu - Wydział Medyczny, Katedra Informatyki i Statystyki (Magdalena Roszak ${ }^{17}$ )

Na ogólnouczelnianym portalu e-learningowym przybyło kursów, do prowadzenia zajęć w trybie synchronicznym wykorzystuje się usługę Microsoft Teams, rośnie liczba materiałów w uczelnianym repozytorium wiedzy (od tego się zaczęło). Działa uczelniane studio nagrań (od roku działa na rzecz tworzenia materiałów multimedialnych) oraz centrum symulacji medycznej (zajęcia on-line $\mathrm{z}$ symulowanym pacjentem). Nauczyciele stosują $\mathrm{w}$ ramach zajęć także inne znane im narzędzia i aplikacje (np. SOCRATIVE), w tym korzystają z zasobów edukacyjnych, jak platforma INCISION (bezpłatny 4-tygodniowy dostęp) czy MEDTube.

Jednostki prowadzące już wcześniej zajęcia e-learningowe czy blended -learning bez żadnych kłopotów przeszły na pełne nauczanie zdalne, wdrażając je szybko także na inne przedmioty. Nauczyciele rozpoczynający pracę zdalną starają się wejść szybko w ten świat edukacji, na miarę swoich możliwości i z uwzględnieniem specyfiki zajęć. Uczelnia publikuje NEWSLETTER DYDAKTYCZNY NA TRUDNE CZASY (co 1,5 tygodnia), aby pokazać przykłady już realizowanych zajęć zdalnych i zachęcić innych do podobnych aktywności.

\section{Uniwersytet Szczeciński - Uczelniane Centrum Informatyczne (Konrad Mielko) \\ Stara wersja Moodle (2.x) z gigantycznym wzrostem wykorzystania (po-} nad 3500 nowych użytkowników, setki kursów), nowa platforma w trakcie instalacji i tworzenia. Do tego Office 365 dla całej uczelni - studenci i pracownicy - czyli głównie Teams, Forms, Stream, Whiteboard (z którym ostatnio jest jakiś problem). Uczenie wykładowców za pomocą TeamViewer i telefonu - indywidualne konsultacje, jak prowadzić zajęcia i obsługiwać oprogramowanie. Niektórzy nauczyciele używają Zoom, ale sesje 40-minutowe w przypadku spotkań akademickich odpadają.

[Komentarz: P.T.] Krótka porada narzędziowa: rzeczywiście sesje są ograniczone do 40 minut, o czym informuja instrukcje i opisy narzędzia. Da sie jednak obejść to ograniczenie. Wystarczy wyjść z sesji podczas jej trwania lub przy zakończeniu i ponownie wejść do niej. Licznik czasu wtedy się zeruje.

Uniwersytet w Białymstoku - Wydział Matematyki i Informatyki (Wiesław Półjanowicz)

$\mathrm{U}$ nas, na Uniwersytecie $\mathrm{w}$ Białymstoku funkcjonuje $\mathrm{z}$ powodzeniem (zresztą od wielu lat) platforma e-learningowa Blackboard (...), która jest

\footnotetext{
${ }_{17}$ Pełnomocnik Rektora UMP ds. e-learningu.
} 
podstawowa dla prowadzenia zajęć zdalnych, zintegrowana z uczelnianym systemem USOS. (...) Dodatkowo są organizowane szkolenia pracownikom poświęcone prowadzeniu sesji on-line (wykłady, ćwiczenia, seminaria) za pomocą Blackboard Collaborate Ultra. Jest to usługa wspomagająca istniejące już na Uczelni środowisko e-nauczania Blackboard Learn.

[Komentarz: P.T.] Poniżej Autor podpowiada inne rozwiazanie ograniczenia sesji w Zoom do 40 minut - tutaj formalne i jednocześnie proste w realizacji.

Oczywiście, można wykorzystywać (i wykorzystywane są) inne platformy e-learningowe, jak na przykład Moodle do prowadzenia zajęć (lub też inne platformy do nauki zdalnej). Do komunikacji synchronicznej wykorzystujemy na Uczelni, oprócz wspomnianego wyżej Blackboard Collaborate, także ZOOM - mamy zniesiony limit 40 minut, należało tylko zarejestrować się w domenie .edu zakładając konto, a Uczelnia została dodana jako jednostka edukacyjna. (...) Poszczególne osoby, z tego co wiem, wykorzystują też inne narzędzia, na przykład BigBlueButton.

Jako ciekawostkę powiem, iż nasi informatycy z Uniwersytetu w Białymstoku stworzyli modelowanie szacujące faktyczną liczbę zakażonych COVID-19 na świecie, co można zobaczyć pod adresem (https:/ / covid-model.net/).

Uniwersytet Warszawski, Wydział Nauk Ekonomicznych (Tomasz Kopczewski)

Wszystko zmieniło się wraz z regulacjami narzuconymi przez prawników. Teamsy prawie zostały zdelegalizowane, Webex całkowicie. Rozwiązania techniczne nie są już problemem, problemem stały się licencje i RODO.

(...) Dla mnie jako ekonomisty innym ważnym problemem jest potencjalna próba oligopolizacji szkół i uniwersytetów przed dwie firmy oraz zastosowanie nowej polityki cenowej opartej na dyskryminacji 1, 2, i 3 stopnia. Po epidemii możemy mieć kompletnie nowy rynek nauczania zdalnego. Ogromny wzrost popytu oraz próby "grodzenia prawnego" ze strony dominujących firm. Bezwiednie epidemia stworzyła potężne narzędzie marketingowe dla tych firm "wymuszone przywiązanie do oprogramowania". Ciekawe, jaka będzie polityka cenowa tych gigantów po zakończeniu epidemii. Sytuacja zmusiła nauczycieli do pracy na rozwiązaniu komercyjnym „chwilowo darmowym". Czy po roku pracy skłonni będziemy przenieść się na inne rozwiązanie/czy raczej będziemy wpływać na nasze instytucje, aby przedłożyć licencje na nowych zasadach.

(...) Dim-Dim przestał istnieć, Webex 49 miesięcznie za 1 hosta. Przeniosłem się ostatecznie na wiziq.com. Płacąc 25\$ miesięcznie za nielimitowaną salę wykładową (bez opcji wideokonferencyjnej). Wiziq niespodziewanie po 2 latach wypowiedział mi umowę, żądając 750\$ miesięcznie za gorsze warunki. 
[Komentarz: P.T.] Powyżej opisana praktyka jest spotykana nie tylko w aplikacjach tworzonych dla edukacji. Jest zreszta powszechnie znana. Na przykład, użytkownik (idąc czasami na skróty) instaluje aplikację i godzi się na warunki wstępne, gdy po jakimś czasie dowiaduje się, że "zasady wstępne" przestana wkrótce obowiazywać i trzeba zakupić licencje komercyjna. Dobrze jest, jeśli w przypadku rezygnacji z opcji płatnej użytkownik nie straci zebranych tam danych $i$ może je pobrać na własny komputer, jednak nie zawsze tak bywa. Stad, zalecana jest ostrożność. Tutejszy przykład Wiziq z narzucona podwyższona drastycznie opłata należy uznać za kuriozalny.

\section{Uniwersytet Warszawski - Wydział Dziennikarstwa, Informacji i Bi- bliologii (Agnieszka Heba)}

Została utworzona specjalna strona ${ }^{18} \mathrm{z}$ informacjami na temat zajęć zdalnych dla wykładowców i studentów.

Ustalono następujące możliwości realizacji zajęć w trybie zdalnym:

1/ Google Meet - pozwala prowadzić zajęcia w trybie telekonferencji. W zajęciach może uczestniczyć do 250 osób, które zapraszamy poprzez e-mail, bądź rozsyłając link.

2/ Google Classroom - możliwy do zajęć, w których pojawiają się projekty przygotowane przez studentów. Można planować dla nich zadania, które studenci mogą wgrywać na platformę.

3/ Platforma UW Kampus ${ }^{19}$ - najbardziej rozbudowana platforma zajęciowa oparta na systemie Moodle. Można zamieścić prezentacje, pliki PDF, linki do materiałów wideo. Dodawać testy, prace pisemne, fora dyskusyjne.

\section{Komentarz końcowy}

Uniwersytet im. Adama Mickiewicza - Wydział Studiów Edukacyjnych (Paweł Topol)

WSE UAM również wspiera aktywnie wszelkie formy kształcenia na odległość w obecnym czasie pandemii - równolegle do Zarządzenia Rektora. $Z$ racji pewnej liczby pracowników mało przygotowanych do sprawnego posługiwania się narzędziami i aplikacjami TIK, władze dziekańskie dały szeroki wybór możliwości korzystania z wszelakich ogólnie dostępnych - według oceny indywidualnej pracownika oraz dostosowania do wiedzy i umiejętności pracownika. Oto wybór: począwszy od wymiany plików w korespondencji indywidualnej lub zbiorowej, przez korzystanie z platformy pracy wirtualnej na wydziale, możliwość zakładania i prowadzenia kursów Moodle, do

\footnotetext{
${ }^{18}$ https:// zajeciazdalne.ckc.uw.edu.pl/\# [dostęp: 15.05.2020].

${ }^{19}$ https://kampus-student2.ckc.uw.edu.pl/ [dostęp: 13.05.2020].
} 
aplikacji obsługujących wideokonferencje w czasie rzeczywistym (MS Teams, Google Classroom, Zoom itd.) oraz inne narzędzia usprawniające proces dydaktyczny i współpracę oraz komunikację w obu kierunkach: wykładowca $\rightleftarrows$ student. Narzędzia te zostały szczegółowo opisane - łącznie z instrukcjami użytkownika - i rozesłane pracownikom. Nieco później wybór narzędzi został ujednolicony przez władze uczelniane i obowiązuje dla całej uczelni.

Chcąc odnieść się do cytowanego wyżej głosu Barbary Kołodziejczak z Wydziału Matematyki i Informatyki UAM, musiałbym powtórzyć większość jej wypowiedzi na temat form wspomagania pracownika. Dotyczy to zarówno Centrum Informatycznego UAM i uczelnianego Ośrodka Wsparcia Kształcenia na Odległość, jak również wydziałowych koordynatorów ds. e-learningu oraz kadry informatyczno-technicznej WSE.

\section{Zakończenie}

Jak wspomniano wyżej, poszczególne wypowiedzi przedstawicieli polskich ośrodków akademickich zostały umieszczone na Forum SEA, z dostępem tylko dla członków Stowarzyszenia. Niniejszy artykuł ma na celu upowszechnienie tych informacji. Być może da to czytelnikowi szersze spojrzenie, jakie kroki i działania były lub są podejmowane w różnych ośrodkach akademickich w kontekście kształcenia zdalnego w dobie pandemii COVID-19.

Tekst artykułu powstawał w lipcu 2020 roku. Do czasu publikacji zapewne wiele zmieni się $\mathrm{w}$ kwestiach organizacji kształcenia zdalnego w polskim szkolnictwie wyższym. Obecnie nie wiadomo, jakie kroki zostaną podjęte względem organizacji dydaktyki. MEN ogłosiło na początku sierpnia, że uczniowie wracają fizycznie do szkól, choć proponowane są różne formy odbywania zajęć: od klasycznego klasowego, poprzez formę mieszaną (hybrydową), do kształcenia zdalnego ${ }^{20}$.

W momencie składania tego tekstu nie pojawiły się jeszcze konkretne wytyczne z MNiSW względem uczelni wyższych, a nawiasem mówiąc, ważną rolę odegra ich autonomia. Jeśli odwołać się do cytowanych wypowiedzi w dyskusji na forum SEA, niektóre uczelnie wydają się być już gotowe na ewentualną kontynuację kształcenia zdalnego w pełnym wymiarze. Oczywiście, ustalenia szczegółowe będą różnić się między poszczególnymi uczelniami czy wydziałami w zależności od specyfiki prowadzonych przez nie form kształcenia: od wykładów i konwersatoriów, do zajęć laboratoryjnych, czy praktyk zawodowych i terenowych.

20 „Bezpieczny powrót do szkół” - Wytyczne MEN, MZ i GIS dla szkół i placówek od 1 września 2020: https://www.gov.pl/web/edukacja/bezpieczny-powrot-do-szkol2 [dostęp: 5.08.2020]. 
Jak wiemy, kształcenie akademickie przeszło całkowicie lub prawie całkowicie na formy wirtualne, które nie były przecież masowo wykorzystywane w uczelniach do tej pory. Powyższej dyskusji na temat możliwości technicznych i sposobów sprostania wyzwaniom towarzyszącym kształceniu zdalnemu $\mathrm{w}$ dobie pandemii towarzyszył drugi wątek na SEA, zatytułowany „A może rekomendacje?". Wnioski płynące z doświadczeń poszczególnych uniwersytetów - choćby na przykładzie cytowanej wyżej dyskusji w SEA mogą być przydatne dla tworzenia pewnych strategii postępowania w najbliższej przyszłości.

Planowana jest następna publikacja, stanowiąca kontynuację niniejszego artykułu, zatytułowana właśnie „Metody i narzędzia kształcenia zdalnego w polskich uczelniach w czasie pandemii COVID-19 - Cz. 2, Rekomendacje 2020". W części teoretycznej zostaną omówione wybrane aspekty e-learningu w obecnych czasach przeobrażeń, między innymi: jak to nauczanie zbiorowe stało się nauczaniem indywidualnym, jak nie "zginąć" w gąszczu nowych ofert narzędzi do pracy on-line dostępnych na rynku, czy jaki jest faktyczny wkład pracy edukatora w przygotowanie kursu on-line i wkład pracy studenta, aby skutecznie w nim uczestniczyć. Część praktyczna będzie podsumowaniem dyskusji przedstawicieli różnych uczelni polskich, wraz z przykładami ich rekomendacji.

\section{BIBLIOGRAFIA}

Bejerano A., The genesis and evolution of online degree programs: who are they for and what have we lost along the way? Communication Education, 2008, 57(3).

Masterson M., An Exploration of the Potential Role of Digital Technologies for Promoting Learning in Foreign Language Classrooms: Lessons for a Pandemic, jJET, 2020, 15, 14.

Reese S., Online learning environments in higher education: Connectivism vs. dissociation, Education and Information Technologies, 2015, 20.

Stowarzyszenie E-learningu Akademickiego - Informacja prasowa, E-mentor, 2006, 4(16).

Urbaniec J., Edukacja "pandemiczna” czyli o ksztatceniu zdalnym na uczelniach, Forum Akademickie, 2020, 05; https://miesiecznik.forumakademickie.pl/czasopisma/fa-052020/edukacja-pandemiczna \% E2\% 80\% A8czyli-o-ksztalceniu-zdalnym-na-uczelniach\%E2\%80\%A9/ [dostęp: 15.06.2020].

\section{Netografia}

Akademia Górniczo-Hutnicza - wtyczki stosowane dla platformy UPEL oraz Virtual Class: (link wewnętrzny uczelni) https://upel.agh.edu.pl/kokpit/wtyczki.html [dostęp: 15.05.2020].

Bezpieczny powrót do szkół - Wytyczne MEN, MZ i GIS dla szkół i placówek od 1 września 2020: https://www.gov.pl/web/edukacja/bezpieczny-powrot-do-szkol2 [dostęp: 5.08.2020]. 
Blog BogusławaŚliwerskiegont. webinariów i ich przydatności edukacyjnej: https:/ / sliwerski-pedagog.blogspot.com/2020/05/jakie-mozliwosci-daja-webinaria.html [dostęp: 15.05.2020].

Modelowanie szacujące faktyczną liczbę zakażonych COVID-19 na świecie, opracowane w Uniwersytecie w Białymstoku: https://covid-model.net/ [dostęp: 12.07.2020].

Ośrodek Wsparcia Nauczania na Odległość UAM, Poznań: https://www.elearning.amu. edu.pl/owko/ [dostęp: 15.04.2020].

Polski Uniwersytet Wirtualny, strona główna: https://www.puw.pl/pl [dostęp: 10.11. 2019].

Polski Uniwersytet Wirtualny, kierunki studiów: https://www.puw.pl/pl/studia-online [dostęp: 10.11. 2019].

Stowarzyszenie E-learningu Akademickiego, certyfikacje e-nauczyciela i e-metodyka: https:/ / sea.edu.pl/certyfikacja.php [dostęp: 15.07.2020].

Stowarzyszenie E-learningu Akademickiego, strona główna: https://sea.edu.pl/ [dostęp: 15.07.2020].

Stowarzyszenie E-learningu Akademickiego, wątek główny dla niniejszego artykułu: „Rozwój e-learningu w obecnych warunkach - jak sobie radzimy?" https://moodle. sea.edu.pl/mod/forum/discuss.php?d=1276 [dostęp: 31.07.2020].

Studium Projektowania Programów Nauczania (2001): http://topol.home.amu.edu.pl/ projekty/ppn.html [dostęp: 15.07.2020].

Uniwersyteckie Centrum Zdalnego Nauczania i Kursów Otwartych Uniwersytetu Marii Curie Skłodowskiej: http://www.uczniko.umcs.lublin.pl/art.php?catID=1\&artID $=1$ [dostęp: 10.05.2016].

Uniwersytet Warszawski - specjalna strona na potrzeby nauczania zdalnego: https:/ / zajeciazdalne.ckc.uw.edu.pl/\# [dostęp: 15.05.2020].

Uniwersytet Warszawski - Platforma US Kampus: https:/ / kampus-student2.ckc.uw.edu. pl/ [dostęp: 13.05.2020]. 